\title{
OPINION
}

\section{Cultural heritage - the first research campus in Hungary}

\author{
Tamas Komives and Zoltan Kiraly \\ Plant Protection Institute, ARC, LERN, Herman Otto 15, Budapest, Hungary \\ E-mail addresses: komives.tamas@agrar.mta.hu and kiraly.zoltan@agrar.mta.hu
}

\begin{abstract}
This article summarizes the authors' views on the agricultural research building complex at 15 Herman Otto street in Budapest, that was established at the beginning of the twentieth century. In 2016, the very first research campus of Hungary, originally established for applied research for practical agricultural objectives, and later shifted also towards fundamental research in life sciences, as well as in ecological and environmental sciences, has been designated a prestigious historical building complex.
\end{abstract}

Keywords -First research campus in Hungary, cultural heritage site, historical building, built heritage, Institute for Ampelology, Plant Protection Institute, Research Institute for Soil Science and Agricultural Chemistry, Budapest

Built heritage is a wealth which, as an important cultural asset, connects us with past generations. Historical buildings are much more than bricks and mortar, they represent status, sociocultural attitudes, and ideas.

- Károly Bugár-Mészáros

Nullum vinum nisi hungaricum.

- Rudolf Lowenstein

The Latin term 'genius loci' (spirit of the place) refers to elements that are tangible (books, buildings, landscape) and intangible (the way the place was used together with the attitudes, morals, ambitions, and priorities of the people who lived and worked there) (Vecco, 2010).

To his paper written on the contributions of Hungarian scientists to modern mathematics and physics, Smil gave the subtitle "The twentieth century was made in Budapest" (Smil, 2001). Rapid advancements in science, research, and industrial development in the late 1800s in Hungary created new schools, universities, and led to the creation of the first research campus in Hungary.

The great financial prosperity of Hungary at the turn of the millennium from the nineteenth to the twentieth century made it possible for the country to establish a world-class research facility to combat the economically threatening grape disease epidemic that swept throughout Europe, wiping out entire vineyard regions from France to the Austro-Hungarian Monarchy. The newly founded research campus was proven to be very successful in both describing and controlling the epidemic, and therefore it continued to expand both infrastructurally and in its research topics. Throughout the next century, the campus, originally founded for practical research purposes, gradually shifted towards fundamental research in agricultural and life sciences. In turn, as ecology gained importance as a newly emerging principle (Odum, 1977; Loreau, 2010), and later as biodiversity and ecosystems research became essential on their own merit (Schoon and Van der Leuw, 2015; Perino et al., 2019), in plant protection chemistry (Komives and Szekacs, 2017), food (Funabashi, 2018), climate (Pecl et al., 2017) and bioeconomy research (Székács, 2017), and in defining the Anthropocene Age (Lewis and Maslin, 2019), environmental sciences and ecotoxicology became essential in its profile.

\section{Cultural history of the research campus}

Following the suggestion of Otto Herman, the Tisza Kalman government established the National Phylloxera Experimental Station in Budapest in 1880 in Debroi Street 15 (today called Herman Otto Street). 


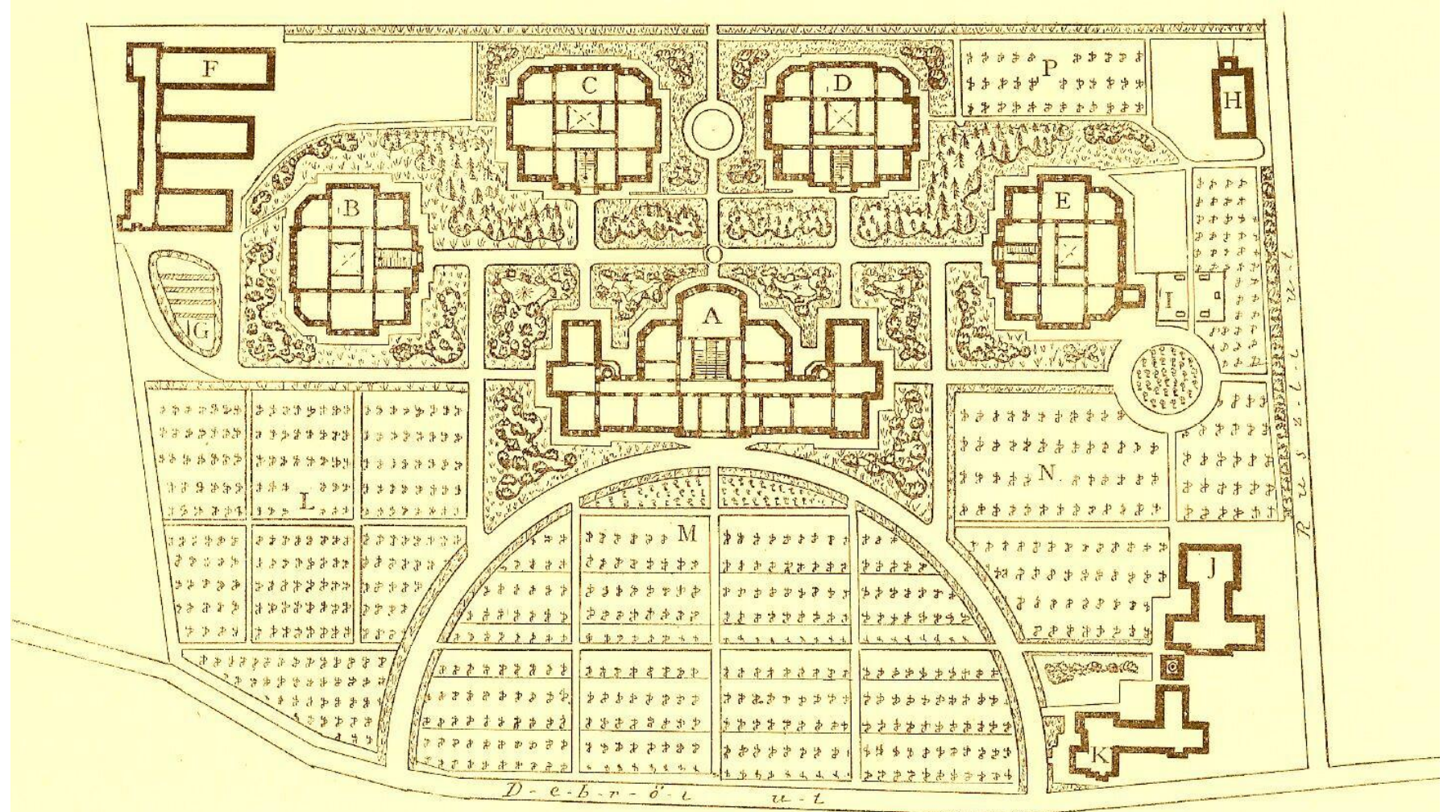

Figure 1. Architectural design of the research campus (Istvanffi, 1907). Buildings: A. Ampelology, B. Biology, C. Wine chemistry, D. Wine fermentation, E. Practical viticulture, F. Greenhouses, H. Personnel, J. Central heating plant. K. Gatekeeper's house.

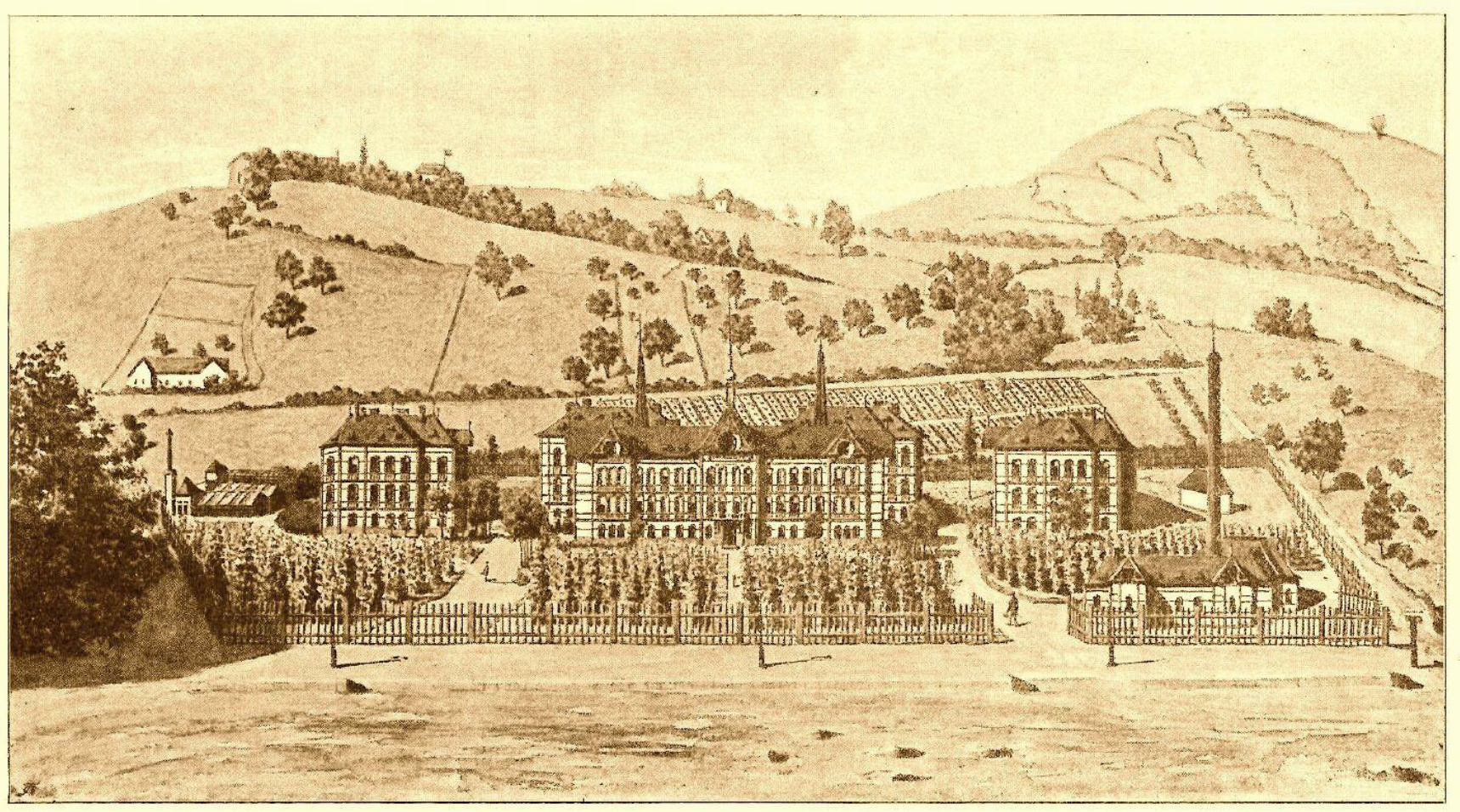

Figure 2. Panoramic view of the research campus (Istvanffi, 1907) 


\section{ECOCYCLES}

The Station's establishment was urgent due to the crisis of viticulture in Hungary caused by the destruction caused by phylloxera (Daktulosphaira vitifoliae) and downy mildew (Plasmopara viticola) introduced from America in the second half of the 19th century. The first report on the activities of the Station has been published in 1882 (Horvath, 1882), followed by a broader, more detailed one in 1885 (Szechenyi, 1885). The Station was reorganized in 1890 to create the Royal Hungarian Entomology Station. Later, on the same site, in order to revive the devastated Hungarian viticulture and winemaking, Article 5 of the Act of Viticulture Revitalization by the minister of agriculture Ignac Daranyi (1896) established the Royal Hungarian Central Vineyard Experimental Station and Institute of Ampelology. The new facility was the first research campus in the country, which is of outstanding scientific importance.

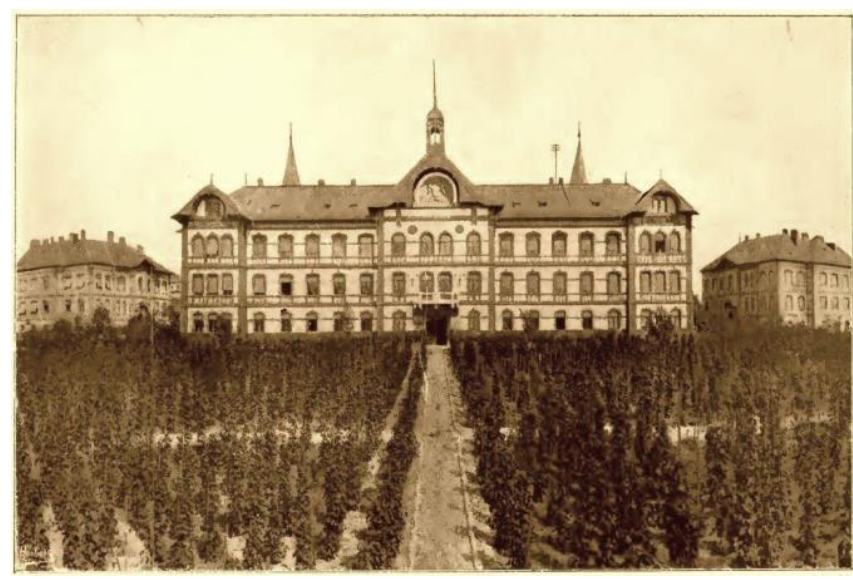

Figure 3. View of the research campus from the South (Alden, 1909)

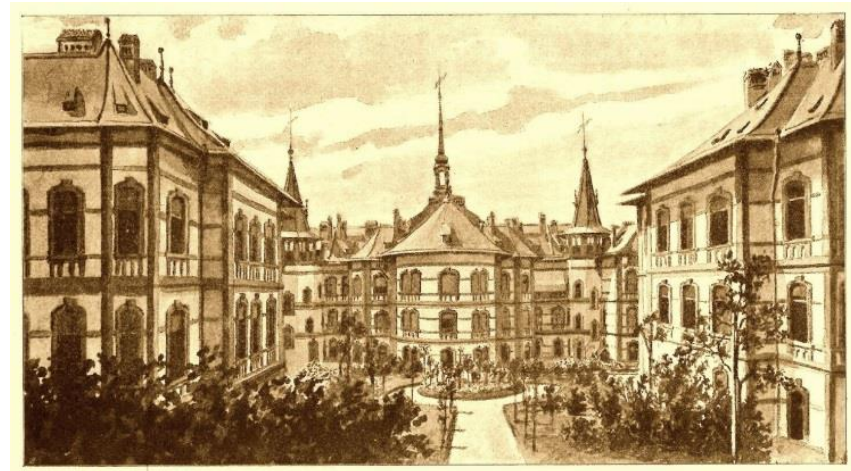

Figure 4. View of the research campus from the North (Istvanffi, 1907)

The impressive architectural plans of the campus occupying 4.5 hectares (Figure 1) were made by one of the most prestigious architects of the time, Gyozo Czigler (professor of architecture at the Budapest Technical University), who, among others, created the plans of the Central Bureau of Statistics, the Gozsdu courtyard, the Saxlehner Palace in Andrassy Street, and the Szechenyi Spa (all in Budapest)
(Sisa, 2016). Building permissions for the campus were issued by the Budapest City Council in 1901. Construction works started rapidly and the buildings entered service in 1904.

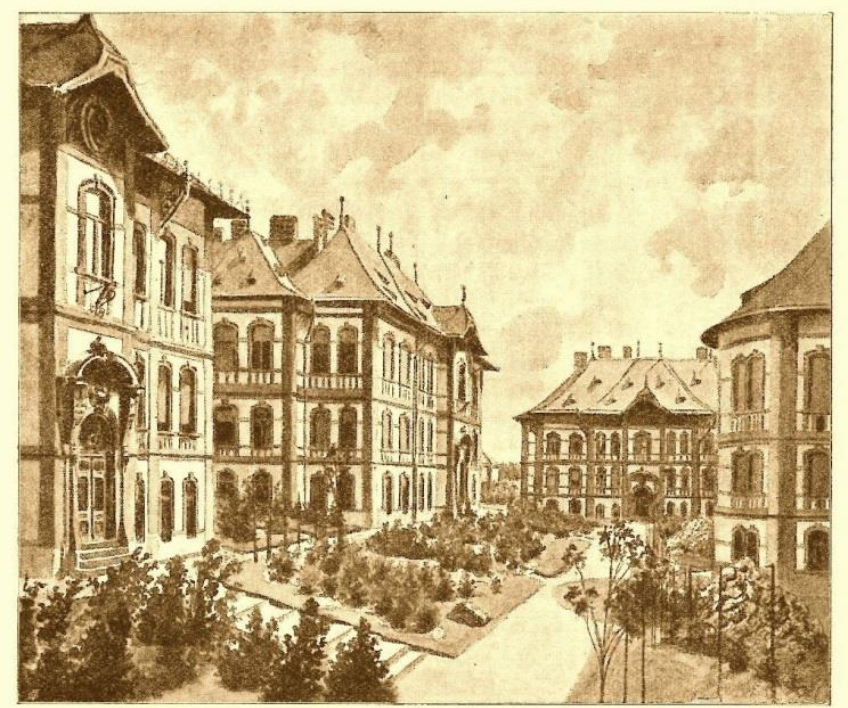

Figure 5. Buildings from left to right: Wine chemistry, Fermentation, and Practical viticulture (Istvanffi, 1907)

Similar to other architectural designs by Gyozo Czigler, the historicist eclectic style of the seven building blocks of the new research campus is of high standard: elaborate roofs evoking the famous castles in the Loire Valley, clinker brick cladding, terracotta decorations on the facades of the buildings, red marble stairs, and wrought iron railings (Figures 1-6). All buildings on the campus were connected with hot-water tubing originated from a central heating plant (see the high chimney on the right-hand corner of the campus in Figure 1).

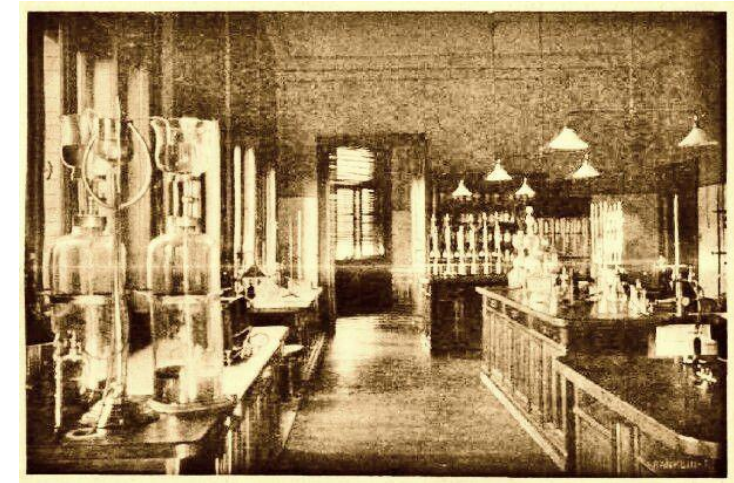

Figure 6. Analytical laboratory of the Ampelology Institute (Istvanffi, 1907)

The internationally renowned research institute also contributed to the training of viticulturists and winemakers: its main building (Figure 3) contained a lecture hall and educational laboratory of the Royal Hungarian Higher Vine 
and Wine School, whose field practice took place in the Institute's vineyards and elegant greenhouses.

The equipment of the research laboratories in the buildings and in the art nouveau style greenhouses (Figure 7) also met the highest demands of the time (e.g. specially ventilated fume hoods and island tables were installed in the chemical and analytical laboratories): a world-class scientific capacity was established, that attracted international recognition.

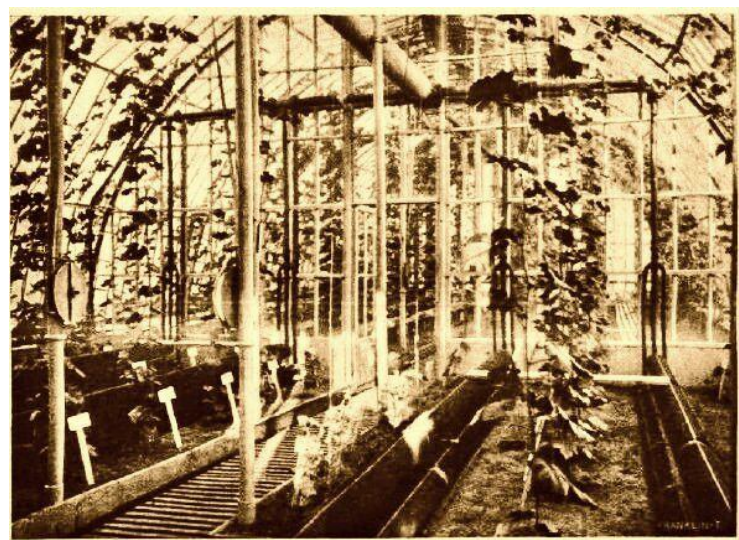

Figure 7. A greenhouse in the campus.

The Institute, together with France, Greece, Italy, Luxembourg, Portugal, Spain, Tunisia, co-participated in the foundation of the International Office of Vine and Wine in Paris in 1924 (Peaslee, 1974). During the First World War, the building complex of the research facility served as a military hospital. Subsequently, a further organizational change took place at the site, in line with the changing needs of state research and development, with the establishment of the Hungarian Royal Center of Ornithology (1909), the Research Institute for Medicinal Plants and Herbs (1920), and the Hungarian Royal Plant Protection Research Institute (1932).
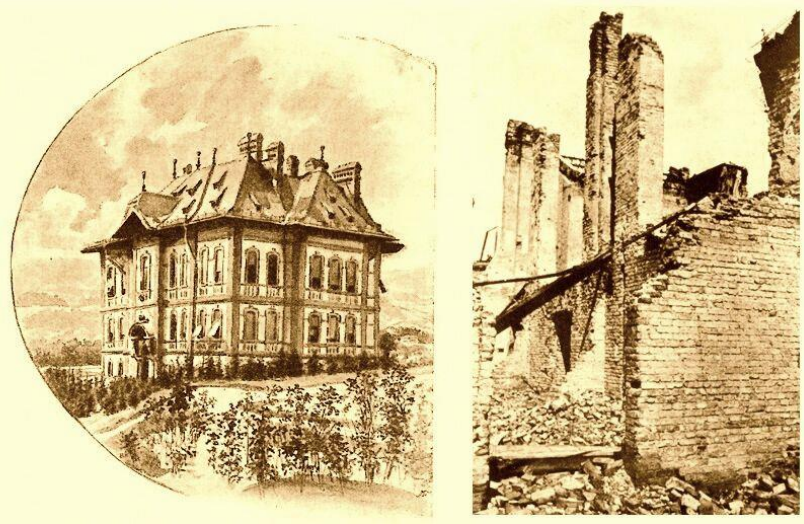

Figure 8. The building of the Plant Protection Institute in 1907 and 1945 (after World War II).

Unfortunately, during the Second World War, at the time of the siege of the Buda Castle, buildings of the campus suffered a great deal of damage (Figure 8), and it took several years to regain their original function and appearance.
After completing the restoration work, the Institute of Genetics (1948), the Institute of Soil Science and Agricultural Chemistry (RISSAC, 1949) and the Research Institute of Canned Food, Meet, and Refrigeration Industry (1949, in 1973 renamed Central Food Research Institute, CFRI) were established. In the meanwhile, three institutes (Ornithology, Medicinal Plants, and Ampelology) were moved out of the campus. Later, RISSAC (1951) and PPI (1981) were handed over to the research institute network of the Hungarian Academy of Science (HAS).

For decades, the structure of the institutes on the campus remained stable - up until very recently. In 2012 CFRI was extended with an Agro-Environmental Safety Division and was renamed to Central Environmental and Food Science Research Institute. In 2013 PPI and RISSAC were merged with the Agricultural Research Institute in Martonvasar when the Agricultural Research Centre (ARC) of HAS was created (the member institutes were able to retain their premises). In 2014 CFRI that remained at the Ministry of Agriculture was merged under the Godollo-based National Agricultural Research and Innovation Centre (NARIC), and within this entity was split into two institutes, the Agro-Environmental Research Institute (AERI) and the Food Science Research Institute (FSRI). In 2019, all institutes of HAS were transferred to the Ministry of Innovation, and the Eotvos Lorand Research Network (ELRN) was created. Today, four research institutes are located on the campus: PPI and RISSAC (parts of ARC, ELRN) and AERI and FSRI (parts of NARIC).

\section{Current research focus}

The four institutes of the campus carry out internationally recognized basic research but have never been reluctant to investigate practical problems in agriculture, food and environmental science.

We believe that this campus of great architectural importance has genius loci, because, during its 112 years of existence it has acquired indelible merits in Hungarian cultural history: it has given a long line of internationally renowned scholars (to date, twenty-two elected members of HAS have been affiliated with the institution as researchers) to Hungarian science. Researchers of the campus achieved major contributions to Hungarian and international science. To mention a few of the most important ones:

- developed a method of controlling phylloxera in sandy soils and an early method to forecast Plasmopara viticola epidemics.

- contributed to the breeding of new wine-fermenting yeast biotypes,

- established up-to-date food preservation and enzymatic technologies,

- achieved numerous breakthroughs in elucidating the mechanisms of plant resistance against viral, bacterial, and fungal pathogens and insect pests,

- recognized a hyperparasitic chain in which a higher plant was parasitized by a fungus, this fungus by a bacterium, and the bacterium by a viral bacteriophage, 
- formulated the concepts of sequential evolution and ecological plant protection,

- designed new sex pheromone traps for monitoring insect pest populations,

- developed immunoanalytical assays and sensors for components and organic microcontaminants of agricultural and food origin serving food and environmental safety,

- characterized pesticide residues and other priority contaminants as surface water and sediment pollutants in Hungary and other countries of the Danube Valley,

- carried out environmental hazard identification of genetically modified crops in the Pannonian Biogeographical Region,

- developed the genetic classification system of Hungarian soils and methodologies for large-scale soil mapping, characterization of soil moisture regime, and soil improvement,

- clarified interactions between microorganisms, soil, and higher plants,

- discovered new phenomena in soil degradation and biogeochemical pollutant cycling.

Most of these results were published in major international journals and books and were cited many many thousand times in the scientific literature.

\section{Concluding remarks}

In 2016 the research campus was designated as a "significant scientific, agricultural, and technical monument of European significance of its age" by the National Heritage and Property Management Center of Gyula Forster on August 11, 2016 (Event no.: 600/2232 -7 / 2016). One can hope that on the basis of the successful past, makers of science policy will find a role for the campus in improving agricultural research in Hungary.

\section{Acknowledgments}

1. The authors thank architectural historian Károly BugárMészáros (Hungarian Architectural Museum) for his professional advice in matters related to the long-term social impacts of built heritage.

2. We acknowledge with thanks the generous help by Mr. Balázs Lukácsi (The Museum and Library of Hungarian Agriculture) and Mrs. Anna Kézdy (retired photographer of PPI) for providing us with valuable information on the early history of the campus.

3. A preliminary account of this work has been published in Hungarian in the Hungarian version of Wikipedia (accessed on September 18, 2019).

\section{References}

Alden, P., 1909. Hungary of To-Day. London, E. Nash.

Daranyi, I., 1896. Promoting the reconstruction of the vineyards in Hungary devastated by phylloxera (in Hungarian), Corpus juris hungarici 1886-1900.
Dazzi, C., Lo Papa, G. (2015). Anthropogenic soils: general aspects and features. Ecocycles, 1(1), 3-8.

DOI: $10.19040 /$ ecocycles.v1i1.23

Funabashi, M., 2018. Human augmentation of ecosystems: objectives for food production and science by 2045 . NPJ Sci. Food 2, 16.

DOI: $\underline{10.1038 / \mathrm{s} 41538-018-0026-4}$

Horvath, G., 1882. Annual report of the Royal Hungarian Phylloxera Station. First year. 1881 (in French) (No. 1). Hungarian Royal Phylloxera Station, Budapest.

Istvanffi, G., 1907. The Hungarian Royal Institute for Ampelology (in French), Pallas. ed. Budapest.

Lewis, S.L., Maslin, M.A., 2019. Defining the Anthropocene. Nature 512 (7542), 171-180.

DOI: $10.1038 /$ nature 14258 .

Loreau, M.L., 2010. Linking biodiversity and ecosystems: towards a unifying ecological theory. Phil. Trans. R. Soc. B 365, 49-60.

DOI: $10.1098 /$ rstb. 2009.0155

Odum, E.P., 1977. The emergence of ecology as a new integrative discipline. Science 195 (4284), 1289-1293.

DOI: $\underline{10.1126 / \text { science.195.4284.1289 }}$

Peaslee, A.J., 1974. International Governmental Organizations, Constitutional Documents. Revised Third Edition. Martinus Nijhoff, The Hague.

Pecl, E.P., Araújo, M.B., Bell, J.D. et al., 2017. Biodiversity redistribution under climate change: Impacts on ecosystems and human well-being. Science 355, eaai9214.

DOI: $10.1126 /$ science.aai9214.

Perino, A., Pereira, H.M., Navarro, L.M. et al., 2019. Rewilding complex ecosystems. Science 364, eaav5570.

DOI: $10.1126 /$ science.eaav5570

Schoon, M., Van der Leuw, S., 2015. The shift toward socialecological systems perspectives: insights into the humannature relationship. Nat. Sci. Soc. 23, 166-174.

DOI: $\underline{10.1051 / \mathrm{nss} / 2015034}$

Sisa, J., 2016. Motherland and Progress, Hungarian Architecture and Design 1800-1900. Birkhäuser, Berlin, Basel.

DOI: $\underline{10.1515 / 9783035610109}$

Smil, V., 2001. Genius loci. Nature 409, 21-21.

DOI: $10.1038 / 35051162$

Szechenyi P., 1885. Report on the viticulture in the Hungarian Kingdom (1882-1884) (In Hungarian). Budapest. 
Szekacs, A., 2017. Environmental and ecological aspects in the overall assessment of bioeconomy. J. Agric. Environ. Ethics 30 (1), 153-170.

DOI: $\underline{10.1007 / \mathrm{s} 10806-017-9651-1}$

Szekacs, A., Komives, T., 2017. Research directions in plant protection chemistry. Ecocycles 3 (2), 4-12.
DOI: $\underline{10.19040 / \text { ecocycles.v3i2.71 }}$

Vecco, M., 2010. A definition of cultural heritage: From the tangible to the intangible. J. Cult. Herit. 11, 321-324.

DOI: $\underline{10.1016 / j . c u l h e r .2010 .01 .006}$

CC (C) 2019 by the author(s). This article is an open-access article distributed under the terms and conditions of the Creative Commons Attribution (CC-BY) license (http://creativecommons.org/licenses/by/4.0/). 